\title{
Prevalence of Aflatoxin Contamination in Maize and Groundnut in Ghana: Population Structure, Distribution, and Toxigenicity of the Causal Agents
}

\author{
D. Agbetiameh, International Institute of Tropical Agriculture (IITA), PMB 5320, Ibadan, Nigeria, and Department of Crop and Soil Sciences, \\ Kwame Nkrumah University of Science and Technology (KNUST), Kumasi, Ghana; A. Ortega-Beltran, IITA, PMB 5320, Ibadan, Nigeria; \\ R. T. Awuah, Department of Crop and Soil Sciences, KNUST, Kumasi, Ghana; J. Atehnkeng, IITA, Chitedze Research Station, P.O. Box \\ 30258, Lilongwe 3, Malawi; P. J. Cotty, United States Department of Agriculture, Agricultural Research Service, School of Plant Sciences, \\ University of Arizona, Tucson, AZ 85721; and R. Bandyopadhyay, ${ }^{\dagger}$ IITA, PMB 5320, Ibadan, Nigeria
}

\begin{abstract}
Aflatoxin contamination in maize and groundnut is perennial in Ghana with substantial health and economic burden on the population. The present study examined for the first time the prevalence of aflatoxin contamination in maize and groundnut in major producing regions across three agroecological zones (AEZs) in Ghana. Furthermore, the distribution and aflatoxin-producing potential of Aspergillus species associated with both crops were studied. Out of 509 samples (326 of maize and 183 of groundnut), $35 \%$ had detectable levels of aflatoxins. Over $15 \%$ of maize and $11 \%$ of groundnut samples exceeded the aflatoxin threshold limits set by the Ghana Standards Authority of 15 and 20 ppb, respectively. Mycoflora analyses revealed various species and morphotypes within the

Aspergillus section Flavi. A total of 5,083 isolates were recovered from both crops. The L morphotype of Aspergillus flavus dominated communities with $93.3 \%$ of the population, followed by Aspergillus spp. with $\mathrm{S}$ morphotype (6\%), A. tamarii $(0.4 \%)$, and A. parasiticus $(0.3 \%)$. Within the L morphotype, the proportion of toxigenic members was significantly $(P<0.05)$ higher than that of atoxigenic members across AEZs. Observed and potential aflatoxin concentrations indicate that on-field aflatoxin management strategies need to be implemented throughout Ghana. The recovered atoxigenic L morphotype fungi are genetic resources that can be employed as biocontrol agents to limit aflatoxin contamination of maize and groundnut in Ghana.
\end{abstract}

Maize (Zea mays L.) and groundnut (Arachis hypogaea L.) are staple crops for billions across the globe (FAOSTAT 2016). However, in warm agricultural areas, both crops are frequently infected by Aspergillus section Flavi fungi (Samson et al. 1981) and contaminated with aflatoxins before, during, and after harvest (Bandyopadhyay and Cotty 2013; Cotty et al. 1994). Aflatoxins are highly toxic and carcinogenic compounds that negatively impact the health of both humans and livestock (Bryden 2012; Wild and Gong 2010). Chronic and/or acute effects, including death, may result after consumption of aflatoxin-contaminated commodities (Gong et al. 2008; Probst et al. 2007). Aflatoxin contamination of various crops also impacts trade and economic growth. Commodities exceeding aflatoxin thresholds cannot enter premium markets, particularly in developed countries where aflatoxins are strictly monitored and regulated (van Egmond et al. 2007; Wu 2004, 2015).

The most common aflatoxin-producing species worldwide is Aspergillus flavus Link (Klich 2007). This species is subdivided into two distinct morphotypes, $\mathrm{L}$ and $\mathrm{S}$, which vary widely in morphology, epidemiology, and physiology, including their potential to produce aflatoxins (Cotty 1989; Mehl et al. 2012). The L morphotype produces fewer, larger sclerotia (avg. diameter $>400 \mu \mathrm{m}$ ), numerous conidia, and variable levels of aflatoxins, while the $S$ morphotype produces abundant small sclerotia (avg. diameter $<400 \mu \mathrm{m}$ ), few conidia, and consistently high levels of aflatoxin (Cotty 1989). The S morphotype often constitutes a minor proportion of the aflatoxigenic communities associated with a crop but is considered an important causal agent of

${ }^{\dagger}$ Corresponding author: R. Bandyopadhyay;

E-mail: R.Bandyopadhyay@cgiar.org

This study was funded by the Meridian Institute (9678.3 IITA (BC) 2012) on behalf of Partnership for Aflatoxin Control in Africa (PACA), the Bill \& Melinda Gates Foundation (OPP1133356), and the USDA-Foreign Agricultural Service (58-3148-2-246). This work was undertaken as part of the CGIAR Research Program on Agriculture for Nutrition and Health (A4NH).

Accepted for publication 15 October 2017.

Copyright $\odot 2018$ The Author(s). This is an open access article distributed under the CC BY 4.0 International license. contamination because of its capability to produce high aflatoxin levels (Cardwell and Cotty 2002; Jaime-Garcia and Cotty 2010; Probst et al. 2010). Fungal examination of toxigenic communities across the globe has revealed that there are several lineages of fungi with $S$ morphotype with some of them producing large concentrations of both B and $G$ aflatoxins. For instance, in West Africa, there is a group of fungi with $\mathrm{S}$ morphotype that uniformly produces both $\mathrm{B}$ and $\mathrm{G}$ aflatoxins and known as unnamed taxon $\mathrm{S}_{\mathrm{BG}}$ (Atehnkeng et al. 2008; Cotty and Cardwell 1999; Diedhiou et al. 2011; Perrone et al. 2014; Pildain et al. 2008; Probst et al. 2014).

Certain genotypes of the A. flavus $\mathrm{L}$ morphotype are atoxigenic (i.e., do not produce aflatoxins) as a result of genetic defects in one or several genes necessary for aflatoxin production (Chang et al. 2005; Donner et al. 2010). Atoxigenic L morphotype genotypes are relatively common in any given area (Atehnkeng et al. 2008; Cotty 1997; Jiang et al. 2009; Mauro et al. 2015; Ortega-Beltran et al. 2016; Probst et al. 2011; Zanon et al. 2013), while atoxigenicity in $\mathrm{S}$ morphotype genotypes has been reported only once in an isolate collected in the U.S. (Horn and Dorner 1999).

In Ghana, maize and groundnut are major staple crops for the majority of the population (MoFA 2011). Maize is produced in all agroecological zones (AEZs) within Ghana, mostly under rainfed conditions, and primarily by smallholder farmers (Agyare et al. 2014). More than $90 \%$ of groundnut production in Ghana is concentrated in the Northern, Upper East, and Upper West regions, which lie within the Southern Guinea Savanna (SGS) and Derived Savanna (DS) AEZs (MoFA 2011), where the crop is an important source of revenue for many farmers.

Consumption of both maize and groundnut results in high human aflatoxin exposure in Ghana. However, most Ghanaians have little to no knowledge of either what aflatoxins are or the health risks posed by these toxins (Awuah et al. 2008). Aflatoxin awareness is low in spite of frequent reports of aflatoxin contamination of foods for over five decades in Ghana (Beardwood 1964; Kpodo et al. 1996; Kumi et al. 2014; Mintah and Hunter 1978) and surveys describing aflatoxin toxicological effects in Ghanaians, particularly among women and children (Afum et al. 2016; Apeagyei et al. 1986; Jiang et al. 2005; Jolly et al. 2006; Lamplugh et al. 1988; Shuaib et al. 2012). The trade sector has been affected as well. Commodities from Ghana (peanut butter, spices, and edible seeds) exceeding tolerance thresholds have been rejected in European borders (RASFF 2017). As a 
consequence, Ghana faces a threat of an export ban of aflatoxinsusceptible commodities if necessary actions to reduce aflatoxin levels in trade commodities are not taken (Dzirasah 2015). Trade restrictions have affected several other African nations due to high aflatoxin crop content, resulting in severe economic losses (Bandyopadhyay et al. 2016; RASFF 2017).

Many technologies limit crop aflatoxin contamination. These include good agricultural practices, monitoring and crop destruction, and postharvest interventions (Florkowski and Kolavalli 2013; Hell et al. 2008; Jaime-Garcia and Cotty 2004; Jones 1987). Because the aflatoxin contamination process often starts in the field, interventions are needed before crop maturity (Cotty 2006; Dorner 2004). In Ghana, efforts to reduce aflatoxin contamination of maize and groundnut have been directed to postharvest strategies and improvement of storage conditions (Florkowski and Kolavalli 2013). Such interventions may significantly decrease further aflatoxin accumulation after harvest but will not impact preharvest aflatoxin contamination in the field.

The most effective and proven method for prevention of aflatoxin contamination is to use atoxigenic strains of A. flavus as biocontrol agents to decrease the proportion of toxigenic fungi in treated fields (Bandyopadhyay et al. 2016; Wu et al. 2008). This results in significantly less aflatoxin concentrations in crops from treated fields in comparison with crops from untreated fields grown in the same area, in the same cropping season. In the U.S., hundreds of thousands of hectares are treated annually with biocontrol agents and this allows production of crops meeting aflatoxin standards (Cotty 2006; Dorner 2004, 2009; Doster et al. 2014). Nigeria, Kenya, and Senegal are African nations that have successfully adopted aflatoxin management strategies by employing native atoxigenic strains as biocontrol agents; other African nations are in the process of developing this strategy (Bandyopadhyay et al. 2016). Adoption of aflatoxin biocontrol technologies in Ghana for use in maize and groundnut would potentially reduce both aflatoxin concentrations in these crops and consequently human exposure to the toxins. However, implementation of aflatoxin biocontrol technologies within Ghana is dependent on identifying atoxigenic isolates among communities of aflatoxin-producing fungi associated with both maize and groundnut produced in Ghana. Use of native atoxigenic strains adapted to local agroecosystems ensures a greater displacement of aflatoxin-producing strains in comparison with exotic atoxigenic strains that may lack adaptation to compete for local resources (Mehl et al. 2012; Probst et al. 2011). In addition, use of native atoxigenic strains have greater acceptance by regulatory agencies (Bandyopadhyay et al. 2016).

The population structure, distribution, and toxigenicity of aflatoxinproducing fungi associated with maize and groundnut in Ghana remains to be investigated. In addition, little is known about which areas within Ghana are hotspots for aflatoxin contamination of maize and groundnut. Generating knowledge of the interaction of aflatoxin-producing fungi with both maize and groundnut in major producing areas of Ghana is critical to designing aflatoxin management strategies. Therefore, the objectives of this study were to i) determine the prevalence of aflatoxin contamination in maize and groundnut from major producing AEZs in Ghana, ii) assess the population structure and distribution of the etiologic agents of aflatoxin contamination across three AEZs, and iii) determine aflatoxin-producing potentials of communities residing within three AEZs to identify atoxigenic strains of $A$. flavus that can be used in aflatoxin biocontrol programs. Our results highlighted the extent of aflatoxin contamination in maize and groundnut in Ghana and identified areas prone to contamination. In addition, a large germplasm collection of atoxigenic $A$. flavus L morphotype isolates was identified. These native atoxigenic strains of $A$. flavus constitute genetic resources with the potential for use as biocontrol agents to reduce aflatoxin contamination in maize and groundnut throughout Ghana.

\section{Materials and Methods}

Area of study. Maize and groundnut are produced primarily within seven regions of Ghana spanning three AEZs: the SGS, the DS, and the Humid Forest (HF). Figure 1 provides information on the location of sampling sites.
Minor and major cropping seasons. The bimodal rainfall pattern in the HF and the southern parts of the DS enables two cropping seasons: the major and minor seasons. The major season is characterized by heavy precipitation from April to July, followed by a humid period in August (Nkrumah et al. 2014). The minor cropping season begins from September to November and is followed by the Harmattan season from December to March. The Harmattan season is a dry period in which dust blown from the Sahara desert reaches large portions of West Africa, including Ghana (Oppong-Anane 2006). On the other hand, the northern part of the DS encompassing the Northern region and the entire SGS (Upper East and Upper West regions) is characterized by a unimodal rainfall pattern, allowing for only one growing season (major season) occurring between May and November (Nkrumah et al. 2014).

Sample collection and preparation. Maize and groundnut samples were collected from farmers' storage structures during March of 2013 in seven major producing regions of Ghana (Fig. 1). Samples belong to crops planted during either the major or minor cropping season of 2012, depending on the region and AEZ sampled. Shelled or in-shell groundnuts stored for 2 to 5 months were collected from jute or interlaced polypropylene bags, and in-earth cribs. Maize samples consisted of shelled, husked, or de-husked maize. While shelled maize was stored in interlaced polypropylene bags, husked or dehusked maize ears were stored on raised platforms, wooden cribs, as heaps on bare or cemented floor, or spread on tarpaulin. Representative samples ( 0.5 to $1 \mathrm{~kg}$ ) were collected from each storage type. A total of 509 samples, comprising 326 maize and 183 groundnut samples, were collected. Following phytosanitary certification of the samples by the Plant Protection and Regulatory Services Directorate of Ghana's Ministry of Food and Agriculture, all samples were transported to the Pathology and Mycotoxin laboratory of the International Institute of Tropical Agriculture (IITA) for laboratory analyses under import permits issued by Nigeria Agricultural Quarantine Service. Immediately after arrival at the laboratory, ears of maize and podded groundnut samples were shelled manually. Samples were thoroughly mixed and a half portion was blended using a laboratory blender (Waring Commercial, Springfield, MO) for $30 \mathrm{~s}$ in a 110-ml stainless steel blending jar (MC-2) and stored at $4{ }^{\circ} \mathrm{C}$ before aflatoxin and microbial analyses. The blending jar was washed between samples with $80 \%$ ethanol to prevent cross contamination by both microorganisms and aflatoxins.

Aflatoxin analysis. Aflatoxins were extracted from maize by combining $20 \mathrm{~g}$ ground samples with $100 \mathrm{ml} \mathrm{70 \%} \mathrm{methanol} \mathrm{(Atehnkeng}$ et al. 2008). For groundnut, $20 \mathrm{~g}$ ground samples were combined with $100 \mathrm{ml} \mathrm{80 \%} \mathrm{methanol} \mathrm{(Cole} \mathrm{and} \mathrm{Dorner} \mathrm{1993).} \mathrm{Suspensions}$ were shaken on a Roto-Shake Genie (Scientific Industries, Bohemia, NY) for $30 \mathrm{~min}$ at $400 \mathrm{rpm}$ and filtered through Whatman No. 1 filter paper (Whatman International Ltd., Maidstone, England). Filtrates were collected in $250 \mathrm{ml}$ separatory funnels, combined with $100 \mathrm{ml}$ distilled water, and extracted twice with $25 \mathrm{ml}$ methylene chloride. The methylene chloride phase was filtered through a bed of $25 \mathrm{~g}$ anhydrous sodium sulfate contained in fluted Whatman No. 4 filter paper, combined, and evaporated to dryness in a fume hood (Cotty and Cardwell 1999). Residues were dissolved in $1 \mathrm{ml}$ methylene chloride and subjected to scanning densitometry. Homogenates were directly spotted $(4 \mu \mathrm{l})$ alongside aflatoxin standards (Supelco, Bellefonte, PA) on thin layer chromatography (TLC) aluminum $(20 \times 10 \mathrm{~cm})$ silica gel $60 \mathrm{~F}_{254}$ plates (Merck, Darmstadt, Germany) and developed with diethyl ether-methanol-water (96:3:1) (Cotty 1997; Probst et al. 2011). Plates were visualized under ultraviolet light $(365 \mathrm{~nm})$ for presence or absence of aflatoxins. Aflatoxins were quantified directly on TLC plates with a scanning densitometer (CAMAG TLC Scanner 3) and quantification software (winCATS 1.4.2, Camag, AG, Muttenz, Switzerland).

Fungal isolation and characterization. Structures of fungal communities associated with maize and groundnut were determined by assigning isolates within Aspergillus section Flavi to their corresponding species and/or morphotypes. Isolates were obtained from each sample by dilution plate technique on modified Rose Bengal agar (MRBA) (Cotty 1994). Briefly, $1 \mathrm{~g}$ of each sample was suspended 
in $10 \mathrm{ml}$ sterile distilled water contained in a $40 \mathrm{ml}$ sterile polystyrene tube, vortexed for $1 \mathrm{~min}$, and plated on MRBA at appropriate dilutions to ensure the recovery of no more than 10 Aspergillus section Flavi colonies per plate. Plates were incubated for 3 days $\left(31^{\circ} \mathrm{C}\right.$, dark). Colonies of Aspergillus section Flavi were identified by macroscopical morphology (Cotty 1989; Klich and Pitt 1988). For each sample, 10 isolates were transferred to $5-2$ agar (5\% V-8 juice [Campbell Soup Company, Camden, $\mathrm{NJ}$ ], $2 \%$ bacto agar [Difco Laboratories Inc., Detroit, MI], $\mathrm{pH}$ 6.0) and incubated in the dark for 5 days at $31^{\circ} \mathrm{C}$ for further characterization. Members of Aspergillus section Flavi were identified based on their colony characteristics and spore ornamentation and classified into species and morphotypes. Within A. flavus, isolates with smooth conidia and large sclerotia (avg. diameter $>400 \mu \mathrm{m}$ ) were classified as L morphotype (Cotty 1989); those with numerous small sclerotia (avg. diameter $<400 \mu \mathrm{m}$ ) were classified as having the $\mathrm{S}$ morphotype. A. parasiticus and A. tamarii were identified by colony color and spore ornamentation (Klich and Pitt 1988). Incidences of Aspergillus section Flavi species in maize and groundnut samples were calculated as colony-forming units (CFU) per $g$ of sample. A total of 5,083 isolates were recovered and maintained as agar plugs (3- $\mathrm{mm}$ diameter) of sporulating cultures in $2 \mathrm{ml}$ sterile distilled water as working cultures, and on silica gel at $4^{\circ} \mathrm{C}$ for long term storage as described by Probst et al. (2011).

In vitro aflatoxin production and analytical determination. The aflatoxin-producing ability of each of the 5,083 isolates of Aspergillus section Flavi was evaluated in sterile, dead-autoclaved maize kernels. Maize was selected as a substrate to examine aflatoxinproducing potentials because true potentials are revealed using a living substrate in comparison with chemical defined media (Probst and Cotty 2012). Five grams of healthy maize grains from a maize batch previously known to be free of aflatoxins were weighed into $40 \mathrm{ml}$ polystyrene glass vials and washed with two exchanges of tap water to remove surface contaminants. This was followed by soaking with $25 \mathrm{ml}$ tap water overnight to allow imbibing adequate moisture for fungal growth. The next day, water was decanted, kernels rinsed with two exchanges of tap water, and water was decanted again. Kernels were sterilized by autoclaving at $121^{\circ} \mathrm{C}$ for $20 \mathrm{~min}$. After autoclaving, kernels were allowed to reach room temperature under aseptic conditions. The sterilized, moistened kernels were independently inoculated with $500 \mu \mathrm{l}$ of a suspension containing approximately $10^{6}$

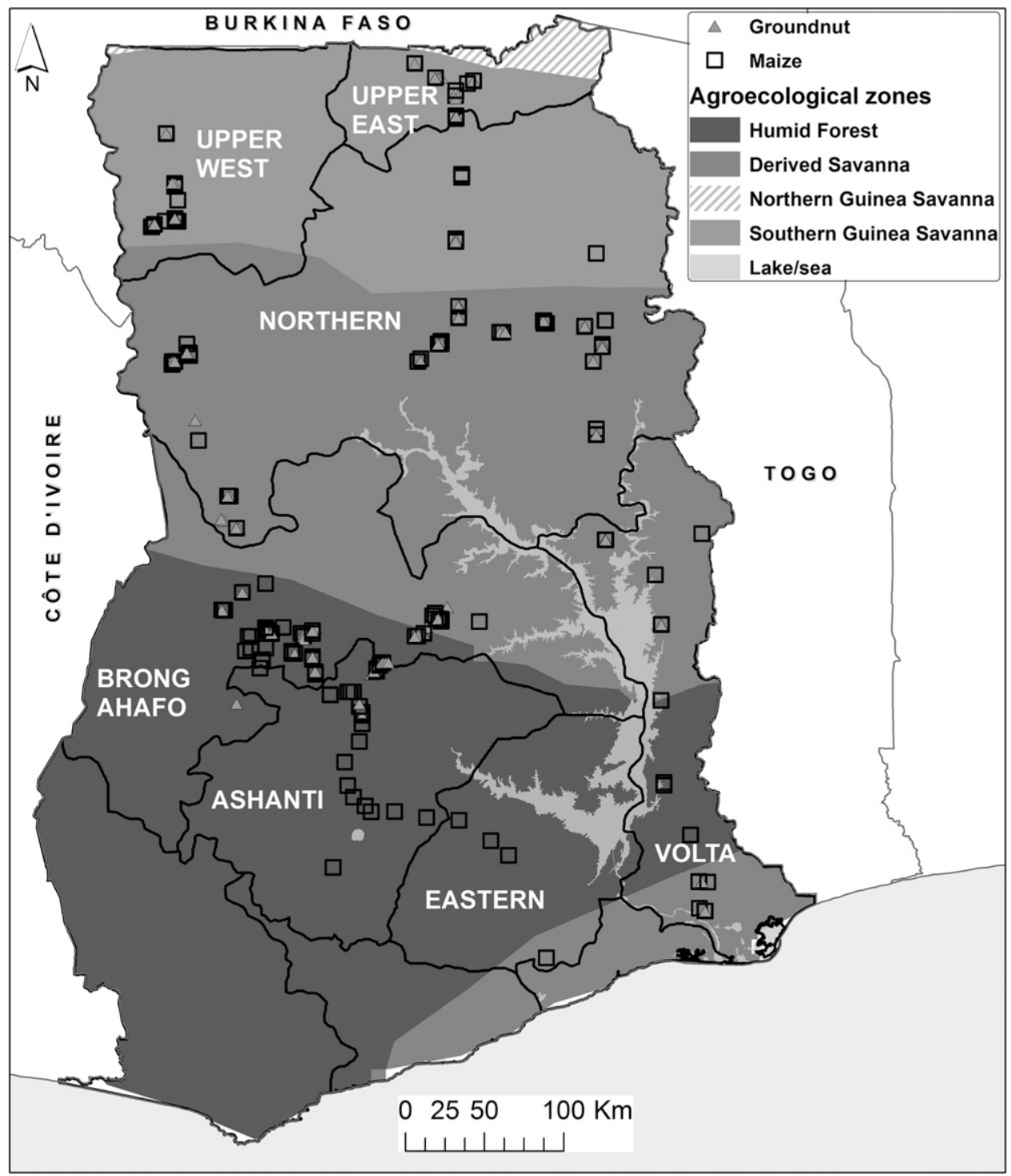

Fig. 1. Map of Ghana depicting agroecological zones and the seven regions where samples were collected. The Southern Guinea Savanna (SGS) zone has a semiarid climate, a unimodal rainfall pattern of up to $1,100 \mathrm{~mm}$, and a growing period of 180 to 200 days. Poor soils low in organic matter with high levels of iron and susceptible to severe erosion are common in SGS. The Derived Savanna (DS) zone has a subhumid climate, an annual precipitation range of 1,000 to $1,500 \mathrm{~mm}$, and a growing period of 180 to 270 days. Soils in DS are principally sandy loams to clay loams, and are mostly poorly drained. The Humid Forest (HF) zone is characterized by a bimodal rainfall pattern ranging from 1,500 to $2,200 \mathrm{~mm}$ and a growing period of 270 to 365 days. Soils in HF are generally loamy, porous, well drained, and have greater accumulation of organic matter in the topsoil in comparison with SGS and DS (MoFA 2011; Oppong-Anane 2006) 
spores of each isolate and incubated at $31^{\circ} \mathrm{C}$ for 7 days in the dark. Kernels inoculated with $500 \mu \mathrm{l}$ of sterile distilled water served as negative control. Aflatoxins were extracted from maize fermentations and quantified as described above. Those maize fermentations from which aflatoxins were not initially detected were extracted, concentrated, and quantified as above. Isolates that did not produce aflatoxins on maize fermentations were classified as atoxigenic. The limit of detection of aflatoxin $\mathrm{B}_{1}$ was 0.1 parts per billion (ppb).

Data analysis. Maize and groundnut samples were grouped into four categories based on their aflatoxin content. The categories were assigned based on aflatoxin limits imposed by the European Union (4 ppb), the Ghana Standards Authority (GSA; $15 \mathrm{ppb}$ for maize and $20 \mathrm{ppb}$ for groundnut), and the United States Food and Drugs Administration (FDA; $20 \mathrm{ppb}$ ) as follows: i) samples with no detectable aflatoxins, ii) $<4 \mathrm{ppb}$, iii) $<15$ (for maize) or $<20 \mathrm{ppb}$ (for groundnut), and iv) $\geq 15$ (for maize) or $\geq 20 \mathrm{ppb}$ (for groundnut).

Values for fungal type incidence, densities, aflatoxin-producing potentials of the recovered fungi, and atoxigenic fungi frequencies in all AEZs, were subjected to analysis of variance (ANOVA) with the general linear model (GLM) suitable for unbalanced data. All statistical tests were performed with SAS (version 9.4, SAS Institute Inc., Cary, NC). The GLM of SAS uses the least-squares method to fit data to a general linear model. Means were separated with the Fisher's protected least significant difference (LSD) test at $5 \%$ significance level. Values for fungal incidences were arcsine square root transformed while values for both fungal densities and aflatoxin-producing potentials were log transformed prior to analysis to normalize the variance. In the tables, nontransformed data are presented.

\section{Results}

Prevalence of aflatoxin contamination in maize and groundnut in Ghana. A majority of the maize and groundnut samples in this study were not contaminated with aflatoxins beyond the threshold limit set by GSA (Table 1). Nevertheless, $15.3 \%$ of maize samples and $11.5 \%$ of groundnut samples exceeded the regulatory limit set by GSA with some maize samples exceeding 22 times and groundnut samples 190 times the GSA limits for human consumption. In general, the aflatoxin contamination level was lower in maize (mean: $11 \mathrm{ppb}$; range: not detectable to $341 \mathrm{ppb}$ ) than in groundnut (mean: $58 \mathrm{ppb}$; range: not detectable to 3,868 ppb) (Table 1).

Aflatoxin concentrations in some AEZs were above tolerance thresholds (Table 2). In maize, mean aflatoxin concentration in DS and SGS was $>15 \mathrm{ppb}$, except in the Eastern region (DS) and Northern region (SGS). Aflatoxin concentration in groundnut from the Volta region (HF), Brong Ahafo and Northern regions (DS), and Northern (SGS), on average, exceeded $20 \mathrm{ppb}$. Some groundnut samples from the Northern region (DS) contained nearly 4,000 ppb total

Table 1. Percent and numbers of maize and groundnut grain samples from Ghana with different levels of aflatoxin concentration

\begin{tabular}{lcc}
\hline \multirow{2}{*}{$\begin{array}{l}\text { Category of aflatoxin } \\
\text { concentration }(\mathbf{p p b})^{\mathbf{x}}\end{array}$} & Percent (number) of crop samples \\
\cline { 2 - 3 } & Groundnut & Maize \\
\hline $\mathrm{ND}$ & $63.4(116)$ & $62.3(203)$ \\
$<4$ & $80.9(148)$ & $70.0(228)$ \\
$<15$ & $\mathrm{~N} / \mathrm{A}^{\mathrm{z}}$ & $84.7(276)$ \\
$\geq 15$ & $\mathrm{~N} / \mathrm{A}$ & $15.3(50)$ \\
$<20$ & $88.5(162)$ & $\mathrm{N} / \mathrm{A}$ \\
$\geq 20$ & $11.5(21)$ & $\mathrm{N} / \mathrm{A}$ \\
\hline${ }^{\mathrm{x}} \mathrm{ND}=$ Not detected; limit of detection $=0.1 \mathrm{ppb} .<4=$ European Union stan- \\
dard; $<20$ (groundnut) and $<15$ (maize) $=$ Ghana Standard Authority standard; \\
$\geq 20$ (groundnut) or $\geq 15$ (maize) = Not fit for human consumption in Ghana. \\
y Percent of crop samples belonging to the indicated category is listed first. \\
Numbers in parenthesis represent number of samples in the indicated category. \\
z N/A = not applicable; aflatoxin tolerance threshold for groundnut in Ghana \\
is 20 ppb. Therefore, the categories of $<15$ and $\geq 15$ were not considered for \\
this crop. Similarly, for maize, the tolerance threshold is 15 ppb, and hence \\
the categories of $<20$ and $\geq 20$ were not considered for this crop.
\end{tabular}

aflatoxins (Table 2). There was no correlation between the types of storage and aflatoxin accumulation (data not shown).

Population structure and distribution of Aspergillus section Flavi. Aflatoxin-producing fungi were detected in all examined samples. A total of 5,083 isolates (3,260 from maize and 1,823 from groundnut) belonging to various species and morphotypes within Aspergillus section Flavi were recovered. The recovered fungi included the $A$. flavus L morphotype, fungi with $\mathrm{S}$ morphotype, A. parasiticus, and A. tamarii. Across the three AEZs, the L morphotype largely dominated the examined communities followed by the $\mathrm{S}$ morphotype. Incidences of both $A$. parasiticus and A. tamarii were rare and inconsistent. A. parasiticus was not detected in SGS. No significant differences $(P=0.05)$ were detected in species or morphotype incidences across AEZs. Significantly $(P<0.05)$ lower fungal densities were detected in HF than in both DS and SGS (Table 3). Further, higher fungal densities were detected in maize than in groundnut and this was significantly $(P<0.05)$ higher in DS and SGS (Table 3).

The L morphotype was consistently the most common Aspergillus group associated with both maize and groundnut. DS was the sole AEZ in which incidences of $\mathrm{L}$ and $\mathrm{S}$ morphotypes differed $(P<0.05)$ between maize and groundnut (Table 3). Similar incidences of isolates

Table 2. Mean and range of aflatoxin concentration ( $\mathrm{ppb}$ ) in stored maize and groundnut samples collected from seven major producing regions in three agroecological zones (AEZs) in Ghana in March 2013

\begin{tabular}{|c|c|c|c|c|c|c|c|}
\hline \multirow[b]{2}{*}{$\mathbf{A E Z} \mathbf{w}^{\mathbf{n}}$} & \multirow[b]{2}{*}{ Region $^{x}$} & \multicolumn{3}{|c|}{$\begin{array}{c}\text { Maize (aflatoxin, } \\
\text { ppb) }\end{array}$} & \multicolumn{3}{|c|}{$\begin{array}{c}\text { Groundnut (aflatoxin, } \\
\text { ppb) }\end{array}$} \\
\hline & & $\overline{n^{y}}$ & Mean & $\overline{\text { Range }}$ & $\overline{n^{y}}$ & Mean & $\overline{\text { Range }}$ \\
\hline \multirow[t]{4}{*}{$\mathrm{HF}$} & Ashanti & 52 & 6.1 & $0-135$ & 12 & 2.2 & $0-17$ \\
\hline & Brong Ahafo & 50 & 0.6 & $0-9$ & 16 & 5.5 & $0-54$ \\
\hline & Eastern $^{\mathrm{z}}$ & 4 & 1 & $0-3$ & - & - & - \\
\hline & Volta & 29 & 9 & $0-83$ & 11 & 42.4 & $0-387$ \\
\hline \multirow[t]{4}{*}{ DS } & Brong Ahafo & 20 & 16.8 & $0-226$ & 27 & 145.6 & $0-1,999$ \\
\hline & Eastern $^{z}$ & 1 & 0 & 0 & - & - & - \\
\hline & Northern & 90 & 15.9 & $0-341$ & 72 & 77.7 & $0-3,868$ \\
\hline & Volta & 8 & 24.2 & $0-157$ & 2 & 0.3 & $0-1$ \\
\hline \multirow[t]{3}{*}{ SGS } & Northern & 14 & 6.8 & $0-59$ & 5 & 34.9 & $0-168$ \\
\hline & Upper East & 15 & 15.4 & $0-82$ & 14 & 0.3 & $0-1$ \\
\hline & Upper West & 43 & 16.4 & $0-190$ & 24 & 15.9 & $0-181$ \\
\hline
\end{tabular}

${ }^{\mathrm{w}} \mathrm{HF}=$ Humid Forest, DS = Derived Savanna, and SGS = Southern Guinea Savanna.

x Samples were collected in regions within different AEZs. For example, in Brong Ahafo, samples from both the HF and DS were collected.

y $n=$ Number of maize/groundnut samples collected and tested for aflatoxin content z Groundnut was not cropped/stored in the sampled areas of the Eastern region at the time of the study.

Table 3. Incidence and densities of Aspergillus section Flavi in maize and groundnut samples across three agroecological zones (AEZs) in Ghana

\begin{tabular}{|c|c|c|c|c|c|c|c|c|}
\hline \multirow[b]{2}{*}{$\mathbf{A} \mathbf{E} \mathbf{Z}^{\mathbf{x}}$} & \multirow[b]{2}{*}{ Crop } & \multirow[b]{2}{*}{$n^{\mathbf{y}}$} & \multicolumn{4}{|c|}{ Incidence $(\%)^{\mathbf{z}}$} & \multicolumn{2}{|c|}{ CFU/g } \\
\hline & & & $\mathbf{L}$ & $\mathbf{S}$ & $A p$ & $A t$ & Mean & Range \\
\hline \multirow[t]{2}{*}{ HF } & Maize & 1,350 & $5.3 \mathrm{a}$ & $4.4 \mathrm{a}$ & $0.0 \mathrm{~b}$ & $0.3 \mathrm{a}$ & $11,819 \mathrm{a}$ & $4-500,000$ \\
\hline & Grour & 38 & $92.1 \mathrm{a}$ & $6.9 \mathrm{a}$ & $0.5 \mathrm{a}$ & $0.5 \mathrm{a}$ & $2,238 \mathrm{a}$ & $2-40,000$ \\
\hline \multirow[t]{2}{*}{ DS } & Maize & 1,190 & $95.0 \mathrm{a}$ & $4.7 \mathrm{~b}$ & $0.0 \mathrm{~b}$ & $0.3 \mathrm{a}$ & $51,940 \mathrm{a}$ & $5-105,000$ \\
\hline & Groundnut & 1,010 & $88.1 \mathrm{~b}$ & $10.6 \mathrm{a}$ & $1.0 \mathrm{a}$ & $0.3 \mathrm{a}$ & $15,122 b$ & $2-666,667$ \\
\hline \multirow[t]{2}{*}{ SGS } & Maize & 720 & $93.1 \mathrm{a}$ & $6.5 \mathrm{a}$ & $0.0 \mathrm{a}$ & $0.4 \mathrm{a}$ & 36,428 a & $5-540,000$ \\
\hline & Groundnut & 430 & $94.6 \mathrm{a}$ & $4.2 \mathrm{a}$ & $0.0 \mathrm{a}$ & $1.2 \mathrm{a}$ & $2,206 \mathrm{~b}$ & $2-36,000$ \\
\hline
\end{tabular}

${ }^{\mathrm{x}} \mathrm{HF}=$ Humid Forest, DS = Derived Savanna, and SGS = Southern Guinea Savanna.

${ }^{\mathrm{y}} n=$ Number of isolates examined.

${ }^{\mathrm{z}}$ Within an AEZ, incidence of each fungus type $(\mathrm{L}=A$. flavus $\mathrm{L}$ morphotype, $\mathrm{S}=$ isolate with $\mathrm{S}$ morphotype, $A p=A$. parasiticus, $A t=A$. tamarii) is compared between crops. For example, in $\mathrm{HF}$, frequencies of the $\mathrm{L}$ morphotype were not significantly different in maize and groundnut. Means with the same letter are not significantly different according to Fisher's least significant difference test $(\alpha=0.05)$. Values for fungal incidences were arcsine square root transformed prior to analyses. Values for fungal densities were $\log$ transformed prior to analysis. 
with $\mathrm{S}$ morphotype were detected in maize and groundnut in both HF and SGS. A. parasiticus was not detected on maize in any AEZ nor in groundnut from SGS.

Aflatoxin production in maize kernels. The causal agents of aflatoxin contamination in Ghana varied in their potential to produce B and $\mathrm{G}$ aflatoxins when inoculated in dead autoclaved maize kernels (Table 4). From the toxigenic fungi, all A. flavus L morphotype isolates produced only $\mathrm{B}$ aflatoxins. Mean aflatoxin-producing abilities of this morphotype varied significantly $(P<0.05)$ across the three AEZs (Table 4), with isolates from SGS producing the highest concentrations. When comparing aflatoxin-producing abilities among types of fungi, significant $(P<0.05)$ differences were detected in each AEZ (Fig. 2, Table 4).

Over $97 \%$ of the isolates with $\mathrm{S}$ morphotype produced large amounts of both B and $\mathrm{G}$ aflatoxins. The remaining isolates (nine total and obtained from a single maize sample) produced no aflatoxins (atoxigenic). The mean aflatoxin $\mathrm{B}_{1}$ production by isolates with S morphotype was significantly $(P<0.05)$ higher in SGS and DS than in HF (Table 4). In addition, the majority $(76 \%)$ of isolates with $\mathrm{S}$ morphotype, uncharacteristically, produced larger concentrations of aflatoxin $\mathrm{G}_{1}$ than of aflatoxin $\mathrm{B}_{1}$ in all three AEZs. All A. parasiticus isolates produced both $\mathrm{B}$ and $\mathrm{G}$ aflatoxins and their aflatoxinproducing potentials did not differ between the two AEZs (HF and DS) only where this species occurred. None of the A. tamarii isolates produced detectable amounts of aflatoxins (Table 4). Within AEZs, all aflatoxin-producing types of fungi (i.e., A. flavus L morphotype, $A$. parasiticus, and isolates with $\mathrm{S}$ morphotype) varied largely in their abilities to produce aflatoxin $\mathrm{B}_{1}$. Isolates with $\mathrm{S}$ morphotype produced significantly $(P<0.05)$ higher amounts of aflatoxin $\mathrm{B}_{1}$ than A. parasiticus and L morphotype in DS and SGS but no significant differences were observed among the three taxa in HF. Across AEZs, the average aflatoxin $B_{1}$ producing potential of each type of fungi was higher in SGS, followed by DS, and the least in HF (Fig. 2).

Distribution of toxigenic and atoxigenic isolates of $A$. flavus L morphotype. Spatial distribution of toxigenic and atoxigenic $\mathrm{L}$ morphotype isolates varied across all three AEZs. Toxigenic isolates were significantly $(P<0.01)$ more prevalent than atoxigenic isolates (Fig. 3). In all, $17.8 \%$ of the tested isolates produced undetectable amounts of aflatoxins and were classified as atoxigenic. The proportion of toxigenic L morphotype members across all three AEZs was $>70 \%$. However, significantly higher $(P<0.05)$ proportions of toxigenic members were observed in SGS and DS in comparison with HF (Fig. 3). Frequencies of toxigenic L morphotype isolates were significantly $(P<0.01)$ higher in groundnut than in maize (Fig. 3$)$.

\section{Discussion}

We document the first extensive study on the occurrence and toxigenicity of aflatoxin-producing species associated with maize and groundnut in major producing areas of Ghana. The causal agents of aflatoxin contamination and the extent of contamination in maize and groundnut across Ghana were determined. Over 35\% of maize and groundnut samples were contaminated with aflatoxins, although concentrations varied among and within AEZs. Our results indicate that both crops are at high risk for aflatoxin contamination with $15.3 \%$ of maize and $11.5 \%$ of groundnut samples exceeding GSA tolerance thresholds (GSA 2001, 2013). Indeed, the mean aflatoxin level in groundnut was nearly three times the GSA threshold. Given the dietary importance of these crops coupled with the fact that the sampled regions are major grain market outlets, it is very likely that most Ghanaians are frequently exposed to aflatoxins (Afum et al. 2016; Jolly et al. 2007; Kumi et al. 2014; Shuaib et al. 2012).

Pre- and postharvest practices largely dictate the extent to which Aspergillus fungi invade seeds and exacerbate aflatoxin production (Cotty 2006; Hell et al. 2008). Insect damage and drought stress prior to harvest favors aflatoxin formation in maize (Hell et al. 2008). Upon maturity, groundnut is dug from the soil and turned upside down haphazardly in a windrow (random windrowing) for curing/ drying in the field (Marfo et al. 2000; Waliyar et al. 2015a). This practice often exposes the crop to warm and moist conditions, which predisposes it to Aspergillus infection and subsequent aflatoxin

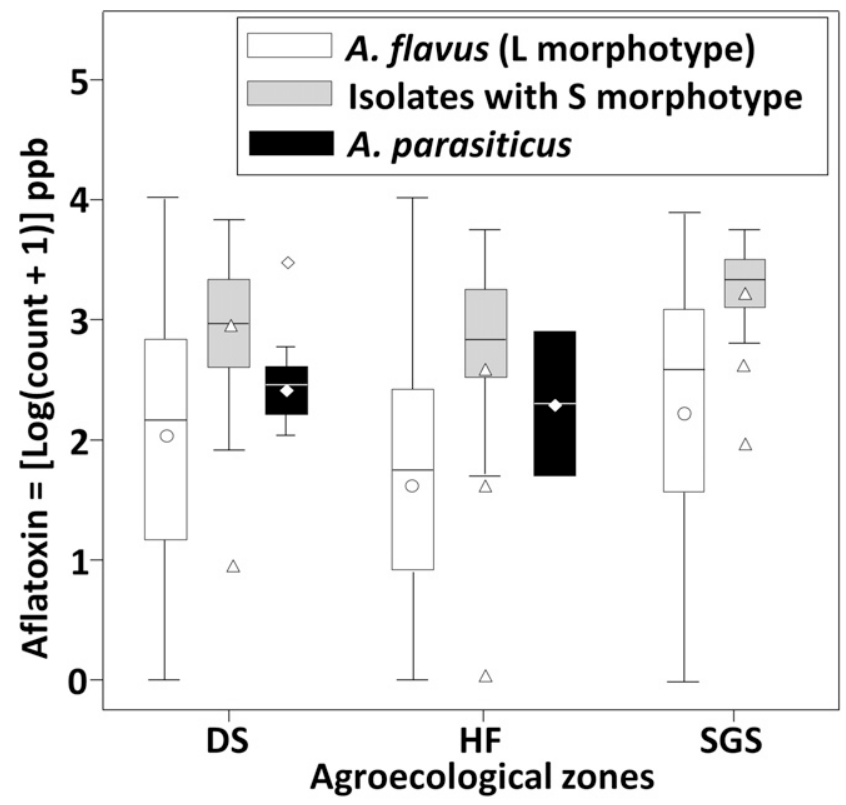

Fig. 2. Box plot showing the variation in quantities of aflatoxin $B 1$ produced by isolates of Aspergillus flavus $\mathrm{L}$ morphotype, isolates with $\mathrm{S}$ morphotype, and $A$. parasiticus across three agroecological zones (AEZs) in Ghana. Boxes indicate the interquartile range of aflatoxin $B_{1}$ produced by each type of fungi within an $A E Z$. Solid lines and symbols inside boxes represent the median and means, respectively. Whisker bars indicate the 10th and 90th percentiles while points below or above whisker bars are outliers. DS $=$ Derived Savanna; $L$ morphotype $=2,020$ isolates, $S$ morphotype $=160$ isolates, $A$. parasiticus $=13$ isolates. $\mathrm{HF}=$ Humid Forest; $\mathrm{L}$ morphotype $=1,639$ isolates, $\mathrm{S}$ morphotype $=86$ isolates, $A$. parasiticus $=2$ isolates. $\mathrm{SGS}=$ Southern Guinea Savanna; $L$ morphotype $=1,077$ isolates, $S$ morphotype $=65$ isolates.

Table 4. Aflatoxin-producing potential of Aspergillus section Flavi isolates in three agroecological zones (AEZs) of Ghana

\begin{tabular}{|c|c|c|c|c|c|c|c|c|c|}
\hline \multirow[b]{3}{*}{$\mathbf{A E Z}^{\mathbf{x}}$} & \multicolumn{9}{|c|}{ Aflatoxin concentration $(\mathbf{p p b})^{\mathrm{z}}$} \\
\hline & \multicolumn{3}{|c|}{ A. flavus L morphotype } & \multicolumn{3}{|c|}{ S morphotype } & \multicolumn{3}{|c|}{ A. parasiticus } \\
\hline & $n^{y}$ & & $\mathbf{B}_{1}$ & $n^{y}$ & $\mathbf{B}_{1}$ & $\mathbf{G}_{1}$ & $n^{y}$ & $\mathbf{B}_{1}$ & $\mathbf{G}_{\mathbf{1}}$ \\
\hline $\mathrm{HF}$ & 1,648 & $\begin{array}{l}\text { Mean }^{\mathrm{z}} \\
\text { Range }\end{array}$ & $\begin{array}{l}299 \mathrm{bC} \\
0-16,673\end{array}$ & 86 & $\begin{array}{c}1,193 \mathrm{aB} \\
0-7,689\end{array}$ & $\begin{array}{c}2,706 \text { aA } \\
0-17,772\end{array}$ & 2 & $\begin{array}{c}492 \mathrm{bA} \\
36-948\end{array}$ & $\begin{array}{c}159 \mathrm{bA} \\
19-298\end{array}$ \\
\hline DS & 2,010 & $\begin{array}{l}\text { Mean } \\
\text { Range }\end{array}$ & $\begin{array}{l}518 \mathrm{bB} \\
0-11,429\end{array}$ & 160 & $\begin{array}{l}1,417 \mathrm{aA} \\
11-7,935\end{array}$ & $\begin{array}{l}1,852 \mathrm{aC} \\
19-10,692\end{array}$ & 13 & $\begin{array}{l}473 \mathrm{bA} \\
111-2,843\end{array}$ & $\begin{array}{l}542 \mathrm{bA} \\
133-2,360\end{array}$ \\
\hline SGS & 1,078 & $\begin{array}{l}\text { Mean } \\
\text { Range }\end{array}$ & $\begin{array}{l}727 \mathrm{bA} \\
0-8,548\end{array}$ & 65 & $\begin{array}{l}1,836 \mathrm{aA} \\
71-6,885\end{array}$ & $\begin{array}{l}2,545 \text { B } \\
125-9,282\end{array}$ & - & - & $\begin{array}{l}- \\
-\end{array}$ \\
\hline
\end{tabular}

${ }^{\mathrm{x}} \mathrm{HF}=$ Humid Forest, DS = Derived Savanna, SGS = Southern Guinea Savanna.

$\mathrm{y}_{n} n=$ Number of isolates.

${ }^{\mathrm{z}}$ Values with the same letter are not significantly different according to Fisher's least significant difference (LSD) test $(\alpha=0.05)$. Lower case letters compare either aflatoxin $B_{1}$ or $G_{1}$ (rows) production within AEZs. Upper case letters compare toxin-production ability of each type of fungi across AEZs (columns). $B_{1}$ and $\mathrm{G}_{1}$ toxins are compared independently. Values for aflatoxin-producing potentials were log transformed prior to analysis. 
production (Cotty and Jaime-Garcia 2007). Further, high aflatoxin levels can occur if rodents and other pests attack and damage pods, and if storage occurs under unfavorable conditions over long periods (Waliyar et al. 2015a, b). On-field drying processes following harvesting along with suboptimal storage conditions possibly influenced the high levels of aflatoxins in groundnut (Table 2). Crop drying under appropriate conditions (e.g., using a mechanical drier to rapidly achieve safe storage moisture content) would have prevented exposure of pods/kernels to moist and/or humid conditions resulting in both reduced pod invasion of aflatoxin-producing fungi and aflatoxin accumulation (Chiewchan et al. 2015; Waliyar et al. 2015b). In areas where the two seasons exist, maize grown during the minor season was collected from farmers' stores. That maize was harvested in December 2012 and stored for around 2 months prior to sampling. The hot Harmattan conditions allow fast and proper drying of the crop in the field prior to harvest and storage. This, together with the short storage period, likely limited aflatoxin concentrations in sampled maize from the minor season (Table 2).

In SGS and a large part of DS (encompassing large areas of the three northern regions; Fig. 1), there is only one cropping season that fits into the category of major cropping season and is characterized by erratic rainfall from May to October. A severe dry period follows until the next season. This dry period allows for fast and proper drying of crops. However, farmers providing samples expressed that prolonged crop storage periods (up to 5 months) are common practice. In Mali, groundnut stored for periods of up to 3 months, in suboptimal conditions, contained high aflatoxin concentrations (Waliyar et al. 2015b). This is expected to occur in susceptible crops stored for similar periods under related conditions in countries within the subregion (Kpodo and Bankole 2008). Indeed, in the current study, we detected high aflatoxin levels in those crops stored for up to 5 months (Table 2) and those crops were associated with higher frequencies of toxigenic fungal types (data not shown). Crop storage under suboptimal conditions results in high levels of aflatoxins if the crop is associated with highly toxigenic fungi (Atehnkeng et al. 2008; Kachapulula et al. 2017).

Nearly four decades ago, Mintah and Hunter (1978) reported high aflatoxin levels in groundnut produced in the Northern and Volta regions that were sold in various markets in Ghana's capital, Accra. It is not clear whether those samples became contaminated with aflatoxins before, during, or after harvest in the producing areas, or during transportation and storage prior to commercialization. In the current study, high aflatoxin levels were detected in both maize and groundnut from the Northern and Volta regions; therefore, it can be hypothesized that samples from the Mintah and Hunter study were indeed contaminated with aflatoxins in the areas in which groundnut were produced. However, the contamination process could have continued during transport and/or storage prior to commercialization. In addition, maize from the Upper East and Upper West (SGS) and groundnut from the Upper West (SGS) and Brong Ahafo (DS) regions had similarly high aflatoxin levels. Our results suggest that the indicated five regions within these AEZs, which constitute major crop-producing areas and market outlets of Ghana, are prone to aflatoxin contamination. Highly contaminated maize and/or groundnut from these regions could reach major markets and consequently homes in Ghana. Efforts targeted at mitigating aflatoxin accumulation of both crops should be primarily designed to be implemented in these regions.

Fungal densities in crops were quantified on a selective medium (MRBA), which allows for maximum detection of Aspergillus section Flavi colonies (Cotty 1994). Higher $(P<0.05)$ fungal quantities $(\mathrm{CFU} / \mathrm{g})$ were obtained in DS (mean $=35,037)$ and SGS (mean $=23,632)$ than HF $($ mean $=9,672)($ Table 3). From November to March, mean monthly temperatures in DS and SGS usually exceed $25^{\circ} \mathrm{C}$, which is an optimum condition for infection and growth of A. flavus (Diener et al. 1987). Thus, inoculum density was expected to be higher in crop samples collected from DS and SGS, which possess a relatively hotter and drier climate than HF. Airborne propagules of Aspergillus section Flavi are the predominant source of primary inoculum for infection of maize while in groundnut the primary source originates from the soil (Wilson and Payne 1994).
In groundnut, the pod walls serve as a physical barrier to infection when kernels are stored in-shell (Nigam et al. 2009). In maize, however, removal of the husk breaks the physical barrier and possibly further exposes the grains to the vagaries of the atmosphere, allowing direct contact and subsequent infection by airborne Aspergillus propagules (Wilson and Payne 1994). Most of the groundnut samples collected for our studies were stored in-shell while most of the collected maize was stored in de-husked form. Those practices are thought to have had a large influence on the variation in propagule densities observed between crop types across AEZs (Table 3). Rapid and adequate drying of groundnut in-shell and maize ears coupled with appropriate storage conditions are crucial for reducing fungal infection and postharvest aflatoxin accumulation.

Communities of Aspergillus section Flavi consist of a complex assemblage of individuals that vary widely in their phenotypic and genotypic characteristics (Cotty et al. 1994; Mehl and Cotty 2010) and represent an important factor in incidences and severities of contamination (Probst et al. 2010). In this study, four types of fungi within Aspergillus section Flavi were identified across three AEZs in Ghana using morphological (colony characteristics and spore ornamentation) and physiological (aflatoxin-producing profile) criteria (Klich and Pitt 1988). Isolates of A. flavus L morphotype dominated all three AEZs (Table 3). However, structures of aflatoxinproducing fungal communities vary among and within AEZs across years (Ortega-Beltran et al. 2015). Fungal community compositions reported in the current study are expected to fluctuate among AEZs in different years.

A community structure similar to the one described in the current study was reported by Perrone et al. (2014) on maize grains from markets and farms at harvest in Ghana and Nigeria. In that study, the L morphotype and a high ( $>70 \%)$ proportion of atoxigenic isolates dominated in samples from Ghana. However, we detected relatively low (17.8\%) frequencies of atoxigenic L morphotype isolates across AEZs (Fig. 3). The use of a living substrate (Probst and Cotty 2012), as used in our study, provides true estimates of aflatoxin-production potential of isolates than chemically defined media as used by Perrone et al. (2014). Occurrence of atoxigenic isolates was expected because atoxigenic isolates have been identified in all regions where aflatoxinproducing communities have been investigated (Abbas et al. 2011; Atehnkeng et al. 2008; Cotty 1989; Mauro et al. 2015; Ortega-Beltran et al. 2016; Wei et al. 2014; Zanon et al. 2013).

Fungal isolates with $\mathrm{S}$ morphotype accounted for $6 \%$ of the examined population. As a group, these isolates produced significantly more $(P<0.0001)$ aflatoxins in maize fermentations than $A$. parasiticus and isolates with L morphotype (Fig. 2, Table 4). The observed high toxigenic potential indicates that fungi with $\mathrm{S}$ morphotype, even at the

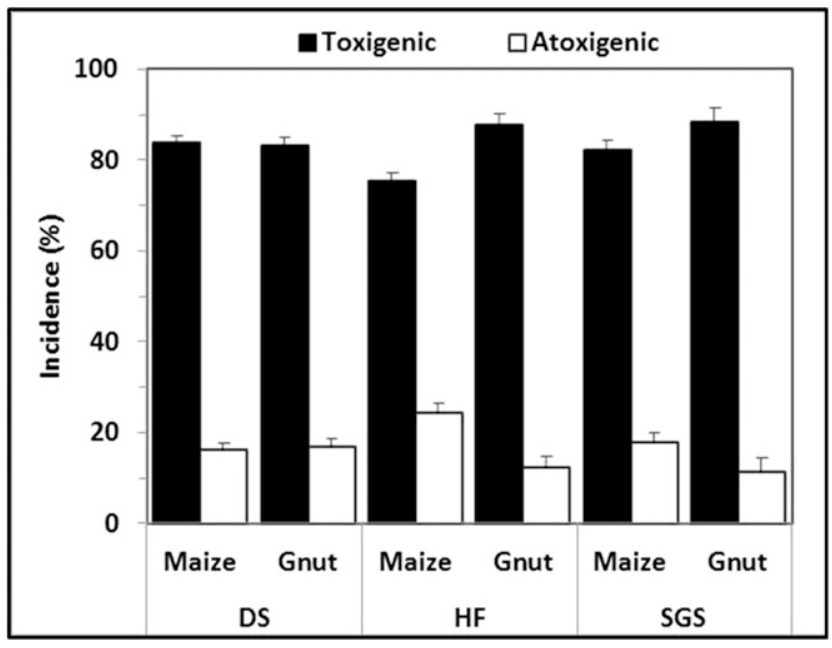

Fig. 3. Distribution of toxigenic and atoxigenic $A$. flavus $L$ morphotype fungi in maize and groundnut (Gnut) across three AEZs of Ghana. For each bar, vertical lines represent the standard error of the means. 
low frequency detected, are important causal agents of aflatoxin contamination in Ghana. Several studies have implicated isolates with $S$ morphotype as the most important causal agent of contamination in regions where dry, hot conditions occur (Cardwell and Cotty 2002; Donner et al. 2009; Ehrlich et al. 2007; Jaime-Garcia and Cotty 2010; Ortega-Beltran et al. 2015; Orum et al. 1997; Probst et al. 2010). Although isolates with $S$ morphotype were detected in all three AEZs, it was more common in both DS and SGS, which are both hotter and drier than HF. In DS and SGS, the relatively high incidences of isolates with $\mathrm{S}$ morphotype in both crops coupled with both prolonged storage and dry, hot temperatures possibly accounted for the high aflatoxin levels detected (Table 2). Aflatoxin management strategies should be designed to target this highly toxigenic group of fungi within these AEZs.

Several phylogenetically divergent groups have been delineated within fungi with $\mathrm{S}$ morphotype using DNA-based techniques (Frisvad et al. 2005; Perrone et al. 2014; Pildain et al. 2008; Probst et al. 2012, 2014; Varga et al. 2011). Previous studies classified a group of isolates with $\mathrm{S}$ morphotype from West Africa as unnamed taxon $\mathrm{S}_{\mathrm{BG}}$ because those isolates uniformly produced both $\mathrm{B}$ and $\mathrm{G}$ aflatoxins (Atehnkeng et al. 2008; Cotty and Cardwell 1999; Diedhiou et al. 2011; Donner et al. 2009). On the contrary, the $S$ morphotype found in the U.S. uniformly produce only B aflatoxins (Cotty 1997; Cotty and Cardwell 1999). In Kenya, isolates with S morphotype were identified as the primary causal agents of severe maize contamination resulting in the most ever recorded human deaths due to aflatoxicosis (Lewis et al. 2005; Probst et al. 2007). However, those Kenyan isolates are phylogenetically distinct from those from the U.S. and other regions across the globe (Probst et al. 2012, 2014).

In our study, 311 isolates were assigned to the $S$ morphotype based on morphological and physiological characteristics. All, except nine isolates of the $\mathrm{S}$ morphotype produced both $\mathrm{B}$ and $\mathrm{G}$ aflatoxins; those nine isolates produced neither B nor $\mathrm{G}$ aflatoxins. The isolates producing both $\mathrm{B}$ and $\mathrm{G}$ aflatoxins possibly belong to the unnamed taxon $\mathrm{S}_{\mathrm{BG}}$ reported only in West African nations (Probst et al. 2014). Atoxigenicity in isolates with $S$ morphotype has been reported only once (Horn and Dorner 1999), although in that study isolates were evaluated in chemically defined media. It is not known if that genotype failed to produce aflatoxins because of a defective aflatoxin biosynthesis gene cluster or because the media utilized was not the appropriate substrate. The nine atoxigenic isolates with $\mathrm{S}$ morphotype were recovered from a single maize sample from the Volta region in HF (data not shown). It is unclear whether those isolates belong to an atoxigenic lineage of the unnamed taxon $\mathrm{S}_{\mathrm{BG}}$ or to other $\mathrm{S}$ morphotype lineages. Molecular characterization would clarify relationships among and within this group of atoxigenic isolates and other groups of isolates with $\mathrm{S}$ morphotype native to Ghana and other regions of the globe.

Generally, aflatoxin $B_{1}$ is the most common aflatoxin produced by aflatoxin-producing species (Mehl et al. 2012). In our study, however, $70 \%$ of the isolates with $\mathrm{S}$ morphotype produced atypically high aflatoxin $G_{1}$ to $B_{1}$ ratios in maize fermentations. Those isolates were recovered in all three AEZs (Table 4). The unusual aflatoxin production profile of certain $\mathrm{S}$ morphotype isolates suggests that in Ghana total aflatoxins rather than only aflatoxin $\mathrm{B}_{1}$ should be considered to determine action levels for crop aflatoxin content. A similar suggestion has been made in Malawi due to the high incidence of aflatoxin G in crops (Matumba et al. 2015).

Few studies report fungi producing higher $G_{1}$ to $B_{1}$ aflatoxin ratios. These include fungal communities examined in Central Europe, Africa, Asia, and the Americas (Baranyi et al. 2015; Cotty and Cardwell 1999; Ehrlich et al. 2007; Kachapulula et al. 2017; Ortega-Beltran and Cotty, unpublished). In crops, higher aflatoxin $G_{1}$ to $B_{1}$ ratios have been reported in naturally contaminated maize from Nigeria (Atehnkeng et al. 2008), and both maize and groundnut from Malawi (Matumba et al. 2015) and Zambia (Kachapulula et al. 2017). In Zambia, the unusual ratios were associated with $A$. parasiticus. In G-type producing species, differences in production of aflatoxin $\mathrm{B}_{1}$ and $\mathrm{G}_{1}$ are related to aflR to aflS expression ratio. Temperatures between 20 and $30^{\circ} \mathrm{C}$ favor higher expression of the aflS gene and subsequently higher biosynthesis of aflatoxin $G_{1}$ as opposed to temperatures $>30^{\circ} \mathrm{C}$, which promote higher aflatoxin $\mathrm{B}_{1}$ biosynthesis (Schmidt-Heydt et al. 2010). However, the temperature in aflatoxinproduction ability tests conducted in the current study was $31^{\circ} \mathrm{C}$. It is unclear if the unusual high aflatoxin $G_{1}$ to $B_{1}$ ratio detected in the $\mathrm{S}$ morphotype fungi is dependent on temperature and/or nutritional composition of the substrate, or due to the isolates' inherent capacity to produce higher quantities of aflatoxin $G_{1}$. Noteworthy, the crop samples from which these isolates were obtained did not contain higher $\mathrm{G}_{1}$ to $\mathrm{B}_{1}$ ratios (data not shown).

Cropping systems influence proportions of Aspergillus section Flavi genotypes in any given area (Jaime-Garcia and Cotty 2010; Mehl and Cotty 2013). Nonetheless, despite differences in cropping systems in the examined AEZs, incidences of each type of fungi were similar (Table 3). There were, however, some differences in proportions of fungi between crops in certain AEZs. For example, highly toxigenic A. parasiticus isolates were detected, albeit at low frequencies, only in groundnut (Table 4), suggesting that A. parasiticus is more commonly associated with groundnut than to maize in Ghana. Similar observations have been made in other regions (Horn 2003). In general, a significantly $(P<0.05)$ higher association of toxigenic $\mathrm{L}$ morphotype (Fig. 3) and both isolates with $\mathrm{S}$ morphotype, and A. parasiticus was detected in groundnut than in maize (Table 3 ). This suggests that in Ghana, groundnut is more prone to aflatoxin contamination than maize. However, because of variability in fungal communities' composition among years and within AEZs, aflatoxin management interventions aimed to exclude toxigenic fungi should be implemented in both crops.

This is the first comprehensive study highlighting prevalence of aflatoxin contamination in major maize and groundnut producing regions in Ghana together with both community structure of causal agents of contamination and their aflatoxin-producing potentials. Hotspot regions for aflatoxin contamination of these crops have been identified based on both environmental conditions favorable for aflatoxin contamination and high frequencies of highly toxigenic fungi, suggesting areas for preferential aflatoxin management efforts. However, studies in additional years should be conducted to determine if crops grown in these regions are perennially at risk of aflatoxin contamination. Furthermore, a fairly large collection of atoxigenic A. flavus L morphotype isolates ( 847 total) has been generated in this study. These atoxigenic isolates are currently being characterized to develop aflatoxin biocontrol management programs for Ghana (Bandyopadhyay et al. 2016). It is necessary to identify native, widely distributed, and competitive atoxigenic genotypes of $A$. flavus associated with crops and/or soils of target AEZs in Ghana. Generating knowledge on the distribution and crop association of atoxigenic L morphotype genotypes throughout Ghana will aid in selecting the best biocontrol candidates to reduce incidences and severities of aflatoxin contamination. Atoxigenic biocontrol of aflatoxins offers an economic, environmentally sound, cost-effective method of aflatoxin mitigation (Bandyopadhyay et al. 2016; Cotty 2006; Mehl et al. 2012; Wu et al. 2008). Implementing aflatoxin biocontrol managements strategies within Ghana would result in improved health, enhanced trade, increased income, and welfare of farmers and consumers.

\section{Acknowledgments}

Special thanks to the maize and groundnut farmers in Ghana for willingly donating samples for this study. We also thank the staff of Ghana's Ministry of Food and Agriculture for assisting in sample collection.

\section{Literature Cited}

Abbas, H. K., Weaver, M. A., Horn, B. W., Carbone, I., Monacell, J. T., and Shier, W. T. 2011. Selection of Aspergillus flavus isolates for biological control of aflatoxins in corn. Toxin Rev. 30:59-70.

Afum, C., Cudjoe, L., Hills, J., Hunt, R., Padilla, L. A., Elmore, S., Afriyie, A., Opare-Sem, O., Phillips, T., and Jolly, P. E. 2016. Association between aflatoxin $\mathrm{M}_{1}$ and liver disease in $\mathrm{HBV} / \mathrm{HCV}$ infected persons in Ghana. Int. J. Environ. Res. Public Health 13:377.

Agyare, W. A., Asare, I. K., Sogbedji, J., and Clottey, V. A. 2014. Challenges to maize fertilization in the forest and transition zones of Ghana. Afr. J. Agric. Res. 9:593-602.

Apeagyei, F., Lamplugh, S., Hendrickse, R., Affram, K., and Lucas, S. 1986 Aflatoxins in the livers of children with kwashiorkor in Ghana. Trop. Geogr. Med. 38:273-276. 
Atehnkeng, J., Ojiambo, P. S., Donner, M., Ikotun, T., Sikora, R. A., Cotty, P. J., and Bandyopadhyay, R. 2008. Distribution and toxigenicity of Aspergillus species isolated from maize kernels from three agro-ecological zones in Nigeria. Int. J. Food Microbiol. 122:74-84

Awuah, R. T., Agyemang, K. O., Fialor, S. C., and Jolly, C. M. 2008. Are Ghanaians aware of the aflatoxin menace? Pages 327-334 in: Mycotoxins: Detection Methods, Management, Public Health and Agricultural Trade. J. F. Leslie, R. Bandyopadhyay and A. Visconti, eds. CABI Publishing, Wallingford, UK.

Bandyopadhyay, R., and Cotty, P. J. 2013. Biological controls for aflatoxin reduction. Pages 44-45 in: Aflatoxins: Finding Solutions for Improved Food Safety. L. Unnevehr and D. Grace, eds. IFPRI, Washington, DC.

Bandyopadhyay, R., Ortega-Beltran, A., Akande, A., Mutegi, C., Atehnkeng, J., Kaptoge, L., Senghor, A. L., Adhikari, B. N., and Cotty, P. J. 2016. Biological control of aflatoxins in Africa: current status and potential challenges in the face of climate change. World Mycotoxin J. 9:771-789.

Baranyi, N., Despot, D. J., Palágyi, A., Kiss, N., Kocsubé, S., Szekeres, A., Kecskeméti, A., Bencsik, O., Vágvölgyi, C., and Klarić, M. Š. 2015. Identification of Aspergillus species in Central Europe able to produce Gtype aflatoxins. Acta Biol. Hung. 66:339-347.

Beardwood, C. 1964. Detection of aflatoxin in groundnut in Accra. Ghana Med. J. 3:87-88.

Bryden, W. L. 2012. Mycotoxin contamination of the feed supply chain: Implications for animal productivity and feed security. Anim. Feed Sci. Technol. 173:134-158.

Cardwell, K. F., and Cotty, P. J. 2002. Distribution of Aspergillus section Flavi among field soils from the four agroecological zones of the republic of Bénin, West Africa. Plant Dis. 79:1039-1045.

Chang, P.-K., Horn, B. W., and Dorner, J. W. 2005. Sequence breakpoints in the aflatoxin biosynthesis gene cluster and flanking regions in nonaflatoxigenic Aspergillus flavus isolates. Fungal Genet. Biol. 42:914-923.

Chiewchan, N., Mujumdar, A. S., and Devahastin, S. 2015. Application of drying technology to control aflatoxins in foods and feeds: a review. Dry. Technol. 33: 1700-1707.

Cole, R. J., and Dorner, J. W. 1993. Extraction of aflatoxins from naturally contaminated peanuts with different solvents and solvent/peanut ratios. J. AOAC Int. 77:1509-1511.

Cotty, P. J. 1989. Virulence and cultural characteristics of two Aspergillus flavus strains pathogenic on cotton. Phytopathology 79:808-814.

Cotty, P. J. 1994. Comparison of four media for the isolation of Aspergillus flavus group fungi. Mycopathologia 125:157-162.

Cotty, P. J. 1997. Aflatoxin-producing potential of communities of Aspergillus section Flavi from cotton producing areas in the United States. Mycol. Res. 101:698-704.

Cotty, P. J. 2006. Biocompetitive exclusion of toxigenic fungi. Pages 179-197 in: The Mycotoxin Factbook. D. Barug, D. Bhatnagar, H. P. van Egdmond, J. W. van der Kamp, W. A. van Osenbruggen, and A. Visconti, eds. Wageningen Academic Publishers, The Netherlands.

Cotty, P. J., Bayman, P., Egel, D. S., and Elias, K. S. 1994. Agriculture, aflatoxins and Aspergillus. Pages 1-27 in: The Genus Aspergillus. K. Powell, ed. Plenum Press, New York.

Cotty, P. J., and Cardwell, K. F. 1999. Divergence of West African and North American communities of Aspergillus section Flavi. Appl. Environ. Microbiol. 65:2264-2266

Cotty, P. J., and Jaime-Garcia, R. 2007. Influences of climate on aflatoxin-producing fungi and aflatoxin contamination. Int. J. Food Microbiol. 119:109-115.

Diedhiou, P. M., Bandyopadhyay, R., Atehnkeng, J., and Ojiambo, P. S. 2011. Aspergillus colonization and aflatoxin contamination of maize and sesame kernels in two agro-ecological zones in Senegal. J. Phytopathol. 159:268-275.

Diener, U. L., Cole, R. J., Sanders, T. H., Payne, G. A., Lee, L. S., and Klich, M. A. 1987. Epidemiology of aflatoxin formation by Aspergillus flavus. Annu. Rev. Phytopathol. 25:249-270.

Donner, M., Atehnkeng, J., Sikora, R. A., Bandyopadhyay, R., and Cotty, P. J. 2009. Distribution of Aspergillus section Flavi in soils of maize fields in three agroecological zones of Nigeria. Soil Biol. Biochem. 41:37-44.

Donner, M., Atehnkeng, J., Sikora, R. A., Bandyopadhyay, R., and Cotty, P. J. 2010. Molecular characterization of atoxigenic strains for biological control of aflatoxins in Nigeria. Food Addit. Contam. 27:576-590.

Dorner, J. W. 2004. Biological control of aflatoxin contamination of crops. J. Toxicol. Toxin Rev. 23:425-450.

Dorner, J. W. 2009. Biological control of aflatoxin contamination in corn using a nontoxigenic strain of Aspergillus flavus. J. Food Prot. 72:801-804.

Doster, M. A., Cotty, P. J., and Michailides, T. J. 2014. Evaluation of the atoxigenic Aspergillus flavus strain AF36 in pistachio orchards. Plant Dis. 98:948-956.

Dzirasah, D. 2015. EU threatens ban over quality of Ghana's cereals. The Ghanaian Times New Time Corporation, Accra, Ghana.

Ehrlich, K. C., Montalbano, B. G., and Cotty, P. J. 2007. Aflatoxin-producing Aspergillus species from Thailand. Int. J. Food Microbiol. 114:153-159.

FAOSTAT. 2016. Statistical databases. Food and Agricultural Organization of the United Nations, Rome, Italy.

Florkowski, W. J., and Kolavalli, S. 2013. Aflatoxin control strategies in the groundnut value chain in Ghana. IFPRI Ghana Strategy Support Program Working Paper 33. IFPRI, Washington, DC.
Frisvad, J. C., Skouboe, P., and Samson, R. A. 2005. Taxonomic comparison of three different groups of aflatoxin producers and a new efficient producer of aflatoxin $\mathrm{B}_{1}$, sterigmatocystin and 3-O-methylsterigmatocystin, Aspergillus rambellii sp. nov. Syst. Appl. Microbiol. 28:442-453.

Gong, Y. Y., Turner, P. C., Hall, A. J., and Wild, C. P. 2008. Aflatoxin exposure and impaired child growth in West Africa: an unexplored international public health burden. Pages 53-65 in: Mycotoxins: Detection Methods, Management, Public Health and Agricultural Trade. J. F. Leslie, R. Bandyopadhyay, and A. Visconti, eds. CABI Publishing, Wallingford, U.K.

GSA. 2001. Nuts - Specification for Groundnut. Ghana Standards Authority, Accra, Ghana.

GSA. 2013. Cereals and Pulses - Specification for Maize (Corn). Ghana Standards Authority, Accra, Ghana.

Hell, K., Fandohan, P., Bandyopadhyay, R., Kiewnick, S., Sikora, R., and Cotty, P. J. 2008. Pre- and postharvest management of aflatoxin in maize: An African perspective. Pages 219-228 in: Mycotoxins: Detection Methods, Management, Public Health and Agricultural Trade. J. F. Leslie, R. Bandyopadhyay, and A. Visconti, eds. CABI Publishing, Wallingford, UK.

Horn, B. W. 2003. Ecology and population biology of aflatoxigenic fungi in soil. J. Toxicol. Toxin Rev. 22:351-379.

Horn, B. W., and Dorner, J. W. 1999. Regional differences in production of aflatoxin $\mathrm{B}_{1}$ and cyclopiazonic acid by soil isolates of Aspergillus flavus along a transect within the United States. Appl. Environ. Microbiol. 64: 1444-1449.

Jaime-Garcia, R., and Cotty, P. J. 2004. Aspergillus flavus in soils and corncobs in South Texas: Implications for management of aflatoxins in corn-cotton rotations. Plant Dis. 88:1366-1371.

Jaime-Garcia, R., and Cotty, P. J. 2010. Crop rotation and soil temperature influence the community structure of Aspergillus flavus in soil. Soil Biol. Biochem. 42:1842-1847.

Jiang, J., Yan, L., and Ma, Z. 2009. Molecular characterization of an atoxigenic Aspergillus flavus strain AF051. Appl. Microbiol. Biotechnol. 83:501-505.

Jiang, Y., Jolly, P. E., Ellis, W. O., Wang, J.-S., Phillips, T. D., and Williams, J. H 2005. Aflatoxin $B_{1}$ albumin adduct levels and cellular immune status in Ghanaians. Int. Immunol. 17:807-814.

Jolly, P. E., Jiang, Y., Ellis, W. O., Awuah, R. T., Appawu, J., Nnedu, O., Stiles, J. K., Wang, J. S., Adjei, O., and Jolly, C. M. 2007. Association between aflatoxin exposure and health characteristics, liver function, hepatitis and malaria infections in Ghanaians. J. Nutr. Environ. Med. 16:242-257.

Jolly, P. E., Jiang, Y., Ellis, W. O., Awuah, R. T., Nnedu, O., Phillips, T., Wang, J.-S., Afriyie-Gyawu, E., Tang, L., and Person, S. 2006. Determinants of aflatoxin levels in Ghanaians: sociodemographic factors, knowledge of aflatoxin and food handling and consumption practices. Int. J. Hyg. Environ. Health 209:345-358.

Jones, R. K. 1987. The influence of cultural practices on minimizing the development of aflatoxin in field maize. Pages 136-144 in: Aflatoxin in maize: A proceedings of the workshop. M. S. Zuber, E. B. Lillehoj and B. L. Renfro, eds. CIMMYT, Mexico, D.F.

Kachapulula, P., Akello, J., Bandyopadhyay, R., and Cotty, P. 2017. Aflatoxin contamination of groundnut and maize in Zambia: observed and potential concentrations. J. Appl. Microbiol. 122:1471-1482.

Klich, M. A. 2007. Aspergillus flavus: the major producer of aflatoxin. Mol. Plant Pathol. 8:713-722.

Klich, M. A., and Pitt, J. I. 1988. Differentiation of Aspergillus flavus from A. parasiticus and other closely related species. Trans. Br. Mycol. Soc. 91:99-108.

Kpodo, K. A., and Bankole, S. A. 2008. Mycotoxin contamination in foods in West and Central Africa. Pages 103-116 in: Mycotoxins: Detection Methods, Management, Public Health and Agricultural Trade, CABI Publishing, Wallingford, U.K.

Kpodo, K. A., Sørensen, A., and Jakobsen, M. 1996. The occurrence of mycotoxins in fermented maize products. Food Chem. 56:147-153.

Kumi, J., Mitchell, N., Asare, G., Dotse, E., Kwaa, F., Phillips, T., and Ankrah, N. 2014. Aflatoxins and fumonisins contamination of home-made food (weanimix) from cereal-legume blends for children. Ghana Med. J. 48:121-126.

Lamplugh, S., Hendrickse, R., Apeagyei, F., and Mwanmut, D. 1988. Aflatoxins in breast milk, neonatal cord blood, and serum of pregnant women. Br. Med. J. (Clin. Res. Ed.) 296:968.

Lewis, L., Onsongo, M., Njapau, H., Schurz-Rogers, H., Luber, G., Kieszak, S., Nyamongo, J., Backer, L., Dahiye, A. M., Misore, M., DeCock, K., and Rubin, C., and the Kenya Aflatoxicosis Investigation Group. 2005. Aflatoxin contamination of commercial maize products during an outbreak of acute aflatoxicosis in eastern and central Kenya. Environ. Health Perspect. 113: 1763-1767.

Marfo, K. O., Denwar, N. N., Adu-Dapaah, H. K., Asafo-Adjei, B., Marfo, K. A., Adjei, J., and Haleegoah, J. 2000. Groundnut production in Ghana. Pages 11-26 in: Proceedings of the national workshop on groundnut and groundnut aflatoxins. R. T. Awuah and W. O. Ellis, eds. UGC Publishing House, Breman-Kumasi, Ghana.

Matumba, L., Sulyok, M., Njoroge, S. M., Njumbe Ediage, E., Van Poucke, C., De Saeger, S., and Krska, R. 2015. Uncommon occurrence ratios of aflatoxin $B_{1}$, $B_{2}, G_{1}$, and $G_{2}$ in maize and groundnut from Malawi. Mycotoxin Res. 31:57-62. Mauro, A., Battilani, P., and Cotty, P. J. 2015. Atoxigenic Aspergillus flavus endemic to Italy for biocontrol of aflatoxins in maize. BioControl 60:125-134 
Mehl, H. L., and Cotty, P. J. 2010. Variation in competitive ability among isolates of Aspergillus flavus from different vegetative compatibility groups during maize infection. Phytopathology 100:150-159.

Mehl, H. L., and Cotty, P. J. 2013. Influence of plant host species on intraspecific competition during infection by Aspergillus flavus. Plant Pathol. 62:1310-1318.

Mehl, H. L., Jaime, R., Callicott, K. A., Probst, C., Garber, N. P., Ortega-Beltran, A., Grubisha, L. C., and Cotty, P. J. 2012. Aspergillus flavus diversity on crops and in the environment can be exploited to reduce aflatoxin exposure and improve health. Ann. N. Y. Acad. Sci. 1273:7-17.

Mintah, S., and Hunter, R. 1978. The incidence of aflatoxin found in groundnuts (Arachis hypogea L.) purchased from markets in and around Accra, Ghana. Peanut Sci. 5:13-16.

MoFA. 2011. Agriculture in Ghana. Facts and figures (2010). Statistics, Research and Information Directorate (SRID), Accra, Ghana.

Nigam, S. N., Waliyar, F., Aruna, R., Reddy, S. V., Lava Kumar, P., Craufurd, P. Q., Diallo, A. T., Ntare, B. R., and Upadhyaya, H. D. 2009. Breeding peanut for resistance to aflatoxin contamination at ICRISAT. Peanut Sci. 36:42-49.

Nkrumah, F., Klutse, N. A. B., Adukpo, D. C., Owusu, K., Quagraine, K. A., Owusu, A., and Gutowski, W., Jr. 2014. Rainfall variability over Ghana: Model versus rain gauge observation. Int. J. Geosci. 5:673-683.

Oppong-Anane, K. 2006. Ghana. Country pasture/forage resources profiles. Food and Agriculture Organization (FAO), Rome, Italy. Available online: http:// www.fao.org/ag/agp/agpc/doc/counprof/PDF\%20files/Ghana-English.pdf.

Ortega-Beltran, A., Grubisha, L. C., Callicott, K. A., and Cotty, P. J. 2016. The vegetative compatibility group to which the US biocontrol agent Aspergillus flavus AF36 belongs is also endemic to Mexico. J. Appl. Microbiol. 120:986-998.

Ortega-Beltran, A., Jaime, R., and Cotty, P. J. 2015. Aflatoxin-producing fungi in maize field soils from sea level to over 2000 masl: A three year study in Sonora, Mexico. Fungal Biol. 119:191-200.

Orum, T. V., Bigelow, D. M., Nelson, M. R., Howell, D. R., and Cotty, P. J. 1997. Spatial and temporal patterns of Aspergillus flavus strain composition and propagule density in Yuma County, Arizona, soils. Plant Dis. 81:911-916.

Perrone, G., Haidukowski, M., Stea, G., Epifani, F., Bandyopadhyay, R., Leslie, J. F., and Logrieco, A. 2014. Population structure and Aflatoxin production by Aspergillus Sect. Flavi from maize in Nigeria and Ghana. Food Microbiol. 41:52-59.

Pildain, M. B., Frisvad, J. C., Vaamonde, G., Cabral, D., Varga, J., and Samson, R. A. 2008. Two novel aflatoxin-producing Aspergillus species from Argentinean peanuts. Int. J. Syst. Evol. Microbiol. 58:725-735.

Probst, C., Bandyopadhyay, R., and Cotty, P. 2014. Diversity of aflatoxinproducing fungi and their impact on food safety in sub-Saharan Africa. Int. J. Food Microbiol. 174:113-122.

Probst, C., Bandyopadhyay, R., Price, L. E., and Cotty, P. J. 2011. Identification of atoxigenic Aspergillus flavus isolates to reduce aflatoxin contamination of maize in Kenya. Plant Dis. 95:212-218.

Probst, C., Callicott, K. A., and Cotty, P. J. 2012. Deadly strains of Kenyan Aspergillus are distinct from other aflatoxin producers. Eur. J. Plant Pathol. 132:419-429.

Probst, C., and Cotty, P. J. 2012. Relationships between in vivo and in vitro aflatoxin production: reliable prediction of fungal ability to contaminate maize with aflatoxins. Fungal Biol. 116:503-510.
Probst, C., Njapau, H., and Cotty, P. J. 2007. Outbreak of an acute aflatoxicosis in Kenya in 2004: Identification of the causal agent. Appl. Environ. Microbiol. 73: 2762-2764.

Probst, C., Schulthess, F., and Cotty, P. J. 2010. Impact of Aspergillus section Flavi community structure on the development of lethal levels of aflatoxins in Kenyan maize (Zea mays). J. Appl. Microbiol. 108:600-610.

RASFF. 2017. The rapid alert system for food and feed (RASFF) - Food and feed safety alerts. Available online: https://ec.europa.eu/food/safety/rasff_en

Samson, R. A., Hoekstra, E. S., and Van Oorschot, C. A. 1981. Introduction to food-borne fungi. Centraalbureau voor Schimmelcultures, Utrecht, The Netherlands.

Schmidt-Heydt, M., Rüfer, C. E., Abdel-Hadi, A., Magan, N., and Geisen, R. 2010. The production of aflatoxin B1 or G1 by Aspergillus parasiticus at various combinations of temperature and water activity is related to the ratio of aflS to aflR expression. Mycotoxin Res. 26:241-246.

Shuaib, F., Jolly, P., Ehiri, J., Ellis, W., Yatich, N., Funkhouser, E., Person, S., Williams, J., Qian, G., and Wang, J. 2012. Socio-demographic determinants of aflatoxin $\mathrm{B}_{1}$-lysine adduct levels among pregnant women in Kumasi, Ghana. Ghana Med. J. 46:179-188.

van Egmond, H. P., Schothorst, R. C., and Jonker, M. A. 2007. Regulations relating to mycotoxins in food: Perspectives in a global and European context. Anal. Bioanal. Chem. 389:147-157.

Varga, J., Frisvad, J. C., and Samson, R. A. 2011. Two new aflatoxin producing species, and an overview of Aspergillus section Flavi. Stud. Mycol. 69 57-80.

Waliyar, F., Osiru, M., Ntare, B., Kumar, K., Sudini, H., Traore, A., and Diarra, B 2015a. Post-harvest management of aflatoxin contamination in groundnut. World Mycotoxin J. 8:245-252

Waliyar, F., Umeh, V., Traore, A., Osiru, M., Ntare, B., Diarra, B., Kodio, O., Kumar, K. V. K., and Sudini, H. 2015b. Prevalence and distribution of aflatoxin contamination in groundnut (Arachis hypogaea L.) in Mali, West Africa. Crop Prot. 70:1-7.

Wei, D., Zhou, L., Selvaraj, J. N., Zhang, C., Xing, F., Zhao, Y., Wang, Y., and Liu, Y. 2014. Molecular characterization of atoxigenic Aspergillus flavus isolates collected in China. J. Microbiol. 52:559-565.

Wild, C. P., and Gong, Y. Y. 2010. Mycotoxins and human disease: a largely ignored global health issue. Carcinogenesis 31:71-82.

Wilson, D. M., and Payne, G. A. 1994. Factors affecting Aspergillus flavus group infection and aflatoxin contamination of crops. Pages 309-325 in: The Toxicology of Aflatoxins. Human Health, Veterinary, and Agricultural Significance. D. L. Eaton and J. D. Groopman, eds. Academic Press, San Diego, CA.

Wu, F. 2004. Mycotoxin risk assessment for the purpose of setting international regulatory standards. Environ. Sci. Technol. 38:4049-4055.

Wu, F. 2015. Global impacts of aflatoxin in maize: trade and human health. World Mycotoxin J. 8:137-142.

Wu, F., Liu, Y., and Bhatnagar, D. 2008. Cost-effectiveness of aflatoxin control methods: Economic incentives. Toxin Rev. 27:203-225.

Zanon, M. A., Chiotta, M., Giaj-Merlera, G., Barros, G., and Chulze, S. 2013 Evaluation of potential biocontrol agent for aflatoxin in Argentinean peanuts. Int. J. Food Microbiol. 162:220-225. 